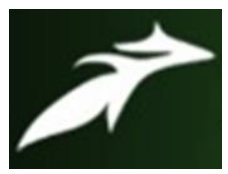

Kanikelli Priyanadh et al, International Journal of Advances in Agricultural Science and Technology,

Vol.8 Issue.1, January-2021, pg. 40-44

ISSN: 2348-1358

Impact Factor: 6.057

NAAS Rating: 3.77

\title{
CONSTRAINTS RELATED TO PRODUCTION AND MARKETING OF INLAND FISH (Catla catla) IN WEST GODAVARI DISTRICT, ANDHRA PRADESH
}

\author{
${ }^{1}$ Kanikelli Priyanadh; ${ }^{2}$ Dr. Sanjay Kumar \\ ${ }^{1}$ Author, M.Sc. Agricultural Economics \\ ${ }^{2}$ Assistant Professor, Dept. of Agricultural Economics \\ SHUATS, Prayagraj-211007 \\ Email: priyanath.k77@ gmail.com \\ DOI: 10.47856/ijaast.2021.v08i1.006
}

\begin{abstract}
Catla catla. Fish is one of the major inland fish produced across the country. West Godavari district of Andhra Pradesh was selected for the study.98 respondents from 4 villages were selected based on the population of the villages. The present study was conducted in the year 2019-2020years.This paper examines the constraints faced by the fish farmers while producing and marketing of the inland fish (Catla catla) which reveals that high cost of seed in production and lack of government support price in marketing are the major constraints expressed by the farmers.
\end{abstract}

Keywords: constraints, inland fish, Catla catla.

\section{Introduction}

The inland fishery sector share was $29 \%$ in 1951, has gone up to more than $50 \%$ in 2003-04, indicating increasing contribution of inland sector to the total fish production. Further, it is ' significant that aquaculture production has increased tremendously during the last decade. Consequently, the percentage share of aquaculture in total inland fish production is estimated to be about $75-80 \%$. Aquaculture has contributed to the bulk as well as value of the inland aquaculture sector. Freshwater Aquaculture resources of the country have been estimated to be of the order of 6.23 million ha, of which 2.25 million ha are in the form of ponds/tanks, 0.827 million ha beels /jheels/ derelict water bodies and 3.15 million ha of reservoirs. The present contribution of 3.5 million tonnes from these resources are hardly commensurate with their vastness and offer the scope for realizing more production with the available technologies in the country. Indian aquaculture is mainly dominated by major carps that account for around $80 \%$ of the total inland fish production. There are a number of potential finfish and shellfish species, catfishes, prawns, 


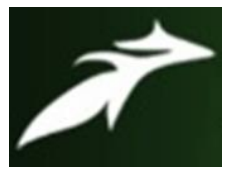

Kanikelli Priyanadh et al, International Journal of Advances in Agricultural Science and Technology, Vol.8 Issue.1, January-2021, pg. 40-44

ISSN: 2348-1358

Impact Factor: 6.057

NAAS Rating: 3.77

ornamental fishes, etc. suitable for different agro-climatic conditions and can be brought under the aquaculture practices. The present study aims to reveal the major constraints faced by the fish farmers in Andhra Pradesh which is one of the major fish producing state in the country. It contributes about 21.86 and 28.45 lakh tonnes in the years of 2017 and 2018 respectively through inland fisheries.

\section{Research Methodology}

The present study is conducted in West Godavari district of Andhra Pradesh in the year of 2020.Multistage randomised sampling has been adopted for the study which involves in selection of Eluru mandal and the villages pydyichinthalapadu, Katlampudi, kalakarru, kokkirailanka. 98 respondents of different categories were selected randomly and data has been collected with the help of well structured and pre tested interview schedule related to the constraints in the region. Statistical tools like percentage and average has been used for the analysis of the study and the results are ranked accordingly.

\section{Results and Discussion}

Constraints faced during production of inland fish(Catla catla.)

Table 1: Constraints related to production of Catla catla in different size of farm groups

\begin{tabular}{|c|c|c|c|c|c|c|}
\hline \multirow[t]{2}{*}{ SI. no } & \multirow[t]{2}{*}{ Particulars } & \multicolumn{3}{|c|}{ Size of Farms Group } & \multirow{2}{*}{$\begin{array}{l}\text { Total in } \\
\text { percentage }\end{array}$} & \multirow[t]{2}{*}{ Rank } \\
\hline & & Small & Medium & large & & \\
\hline 1. & High cost of seed & 40 & 29 & 15 & 85.71 & I. \\
\hline 2. & $\begin{array}{l}\text { Lack of information about } \\
\text { government scheme and subsidies }\end{array}$ & 42 & 27 & 8 & 78.57 & II. \\
\hline 3. & Frequent disease attack & 31 & 24 & 14 & 70.4 & III. \\
\hline 4. & High initial investment & 33 & 19 & 16 & 69.38 & IV. \\
\hline 5. & Fluctuating temperature & 34 & 22 & 10 & 67.34 & V. \\
\hline 6. & High cost of medicines & 31 & 20 & 9 & 61.22 & VI. \\
\hline
\end{tabular}




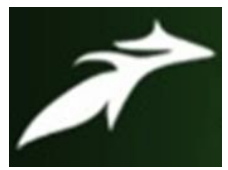

Kanikelli Priyanadh et al, International Journal of Advances in Agricultural Science and Technology, Vol.8 Issue.1, January-2021, pg. 40-44

ISSN: 2348-1358

Impact Factor: 6.057

NAAS Rating: 3.77

\begin{tabular}{|c|l|c|c|c|c|c|}
\hline 7. & High cost of fertilizer & 28 & 17 & 14 & 60.2 & VII. \\
\hline 8. & High cost of labour & 28 & 20 & 9 & 58.16 & VIII. \\
\hline 9. & $\begin{array}{l}\text { Non-availability of labour during } \\
\text { peak period }\end{array}$ & 28 & 17 & 11 & 57.14 & IX. \\
\hline 10. & High cost of manure & 27 & 16 & 8 & 52 & X. \\
\hline 11. & Non-availability of skilled labour & 24 & 18 & 8 & 51.02 & XI. \\
\hline 12. & Lack of irrigation facilities & 23 & 13 & 10 & 46.93 & XII. \\
\hline 13. & $\begin{array}{l}\text { Non-availability of quality seedling } \\
\text { locally }\end{array}$ & 22 & 16 & 7 & 45.91 & XIII. \\
\hline 14. & Shortage of fertilizer & 16 & 17 & 5 & 38.77 & XIV. \\
\hline 15. & Irregular electric supply & 14 & 13 & 4 & 31.6 & XV. \\
\hline
\end{tabular}

Table 1. Shows that constraints faced by the different size of farms group in production of catla catla. Most of the respondents expressed that major constraint was identified that high cost of seed hence awarded rank I, followed by Lack of information about government scheme and subsidies with rank II, Frequent disease attack with rank III, High initial investment with rank IV, Fluctuating temperature with rank V, High cost of medicines with rank VI, High cost of fertilizer with rank VII, High cost of labour with rank VIII, Non-availability of labour during peak period with rank IX, High cost of manure with rank X, Non-availability of skilled labour XI, Lack of irrigation facilities, Non-availability of quality seedling locally with rank XII, Shortage of fertilizer with rank XIII, Irregular electric supply has been awarded with last rank .

Table 2: Constraints related to Marketing of catla catla fish in different Size of Farms Group

\begin{tabular}{|c|l|r|r|r|r|c|}
\hline s.no & particular & Small & Medium & Large & $\begin{array}{l}\text { Total in } \\
\text { percentage }\end{array}$ & rank \\
\hline 1. & $\begin{array}{l}\text { Lack of support prices when there } \\
\text { is glut in the market }\end{array}$ & 40 & 29 & 15 & & I. \\
\hline 2. & $\begin{array}{l}\text { Lack of awareness of new } \\
\text { technologies }\end{array}$ & 39 & 27 & 12 & & II. \\
\hline 3. & $\begin{array}{l}\text { Lack of information about } \\
\text { government schemes and subsidies }\end{array}$ & 37 & 26 & 14 & & III. \\
\hline 4. & $\begin{array}{l}\text { Lack of amenities and facilities in } \\
\text { the market }\end{array}$ & 36 & 27 & 14 & 79.59 & IV. \\
\hline
\end{tabular}




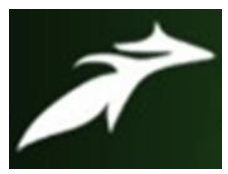

Kanikelli Priyanadh et al, International Journal of Advances in Agricultural Science and Technology, Vol.8 Issue.1, January-2021, pg. 40-44

ISSN: 2348-1358

Impact Factor: 6.057

NAAS Rating: 3.77

\begin{tabular}{|c|l|r|r|r|r|c|}
\hline 5. & Frequent price fluctuations & 38 & & 12 & 75.51 & V. \\
\hline 6. & Delay in cash payment & 33 & 23 & 13 & 70.4 & VI. \\
\hline 7. & $\begin{array}{l}\text { Lack of scientific training about } \\
\text { fish production }\end{array}$ & 34 & 23 & 12 & 70.4 & VII. \\
\hline 8. & High transportation cost & 31 & 25 & 12 & 69.38 & VIII. \\
\hline 9. & $\begin{array}{l}\text { Lack of cooperatives in marketing } \\
\text { Societies at village level }\end{array}$ & 30 & 25 & 10 & & IX. \\
\hline 10. & $\begin{array}{l}\text { Lack of proper infrastructure in } \\
\text { market }\end{array}$ & 32 & 21 & 11 & 66.32 & X. \\
\hline 11. & $\begin{array}{l}\text { Weighing loss } \\
\text { transportation }\end{array}$ & 32 & 22 & 9 & 65.3 & XI. \\
\hline 12. & $\begin{array}{l}\text { Lack of availability of market } \\
\text { information at farm level }\end{array}$ & 28 & 23 & 10 & 64.28 & XII. \\
\hline 13. & \begin{tabular}{l} 
High commission charges \\
\hline
\end{tabular} & & 21 & 11 & & XIII. \\
\hline
\end{tabular}

Table 2. Shows that constraints faced by the different size of farms group in marketing of Catla catla. Most of the respondents expressed that major constraint was identified as "Lack of support prices" when there is glut in the market which has been awarded with rank I, followed by Lack of awareness of new technologies with rank II, Lack of information about government schemes and subsidies with rank III, Lack of amenities and facilities in the market with rank IV, Frequent price fluctuations with rank V, Delay in cash payment with VI, Lack of scientific training about fish production with rank VII, High transportation cost with rank VIII, Lack of cooperatives in marketing societies at village level with rank IX, Lack of proper infrastructure in market with rank $\mathrm{X}$, Weighing loss during transportation with rank XI, Lack of availability of market information at farm level with rank XII and High commission charges with last rank XIII. 


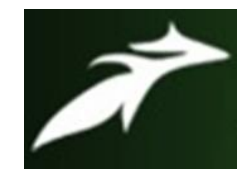

Kanikelli Priyanadh et al, International Journal of Advances in Agricultural Science and Technology, Vol.8 Issue.1, January-2021, pg. 40-44

ISSN: 2348-1358

Impact Factor: 6.057

NAAS Rating: 3.77

\section{Conclusion}

Findings of the present study reveal that major constraints as High cost of seed during production which contributes about one third of the production cost of inland fish and Lack of support from government when there is glut in the market was the marketing constraint faced by the fish farmers. As 85.71 percent of total 98 respondents expressed that the above mentioned constraints as most effecting factors during production and marketing of inland fish. Hence government should consider resolving these constraints.

\section{References}

[1]. Abarham T.J and Vineetha,P (2010).A comparative study of the aquaculture practices adopted by fish farmers in Andhra Pradesh and west Bengal .Indian journal of Fisherires.57 (3),41-48pp.

[2]. Ali,S M (1996).marine fisheries economics and development in India. Marine fisheries economics and development in India, Orissa.(8),12-208pp.

[3]. Anil kumar singh(1996), An economic analysis of production and marketing of fish in Nagra block of Ballia District,UP. Unpublished, M.Sc Agricultural Economics thesis, Allahabad agriculture institute. Deemed University.

[4]. Ayyappan .S and Diwan, A.D (2006). Fisheries research and development in India, Fishing Chimes. Vol.26 No.1.

[5]. Banafar ,singh and Gauraha, A.K.(2007),economics of production and marketing of duck -cum-fish enterprises: a micro level evidence from Chhattisgarh, Agricultural Marketing.50 (3),17-20pp.

[6]. Bhattacharya, H (2002). Commercial exploitation of fisheries: production, marketing and finance strategies.(19),327pp.

[7]. Chauhan S.K.and Moorthi, T.V(1989),economics of reservoir fisheries- a study of fish cooperatives in pond dam area of Himachal Pradesh. Indian cooperative review.26(3),329-337pp.

[8]. http://fisheries.ap.gov.in/

[9]. http://dof.gov.in/

[10].https://krishikosh.egranth.ac.in/

[11].https://westgodavari.ap.gov.in/fisheries/ 